\title{
The value of political independent supervisory boards: Evidence from Indonesian dual board setting
}

\author{
Joni Joni*, Jahja Hamdani Widjaja, Maria Natalia, Ivan Junius Salim \\ Maranatha Christian University, Indonesia
}

ARTICLE INFO

Article history:

Received 13 April 2021

Revised 14 May 2021

Accepted 02 June 2021

Published 07 June 2021

Keywords:

Political I-SBs

Corporate risks

Two-tier board system

\section{ABSTRACT}

We investigate whether political independent supervisory boards (political I-SBs) help companies to reduce their corporate risks in the setting of Indonesian two-tier board system. This study is different from other studies in several ways. First, while most prior studies examine the effectiveness of independent boards in one-tier board setting, we use dual board system. This system promotes the strategic role of political I-SBs. Second, we use two measures of corporate risks: operating and market risks. Based on 1,176 firm-year observations for operating risk analysis and 1,254 firm-year observations for market risk analysis, we find that firms with political I-SBs have lower operating and market risks than firms with nonpolitically connected independent SBs. We also control for endogeneity problem using GMM (Generalized Method of Moments) method, and the results are still consistent.

\section{Introduction}

The value of independent board has been questioned by both academics and practitioners recently. Theoretically, the presence of independent board is expected to create value by mitigating the agency conflicts (Fama and Jensen 1983) and providing resources (Pfeffer and Salancik 1978). However, empirically, it is not clear whether independent board create or destroy value. Shi et al. (2018) provide a strong argument on why the empirical research shows a mixed result. This because Independent boards with different backgrounds can result different behaviors in conducting their main duties, including monitoring, supervising, and providing resources. Therefore, it is important to investigate the type of independent boards and how they can create value.

The objective of this empirical study is to examine the effect of political independent supervisory board (I-SB) as a particular type of independent board on corporate's risks in Indonesian dual board system. In emerging market, political affiliations are valuable resources. Therefore it is common for listed companies to appoint former or current government officers as independent board to maintain their relationship with government. According to Agency Theory, the presence of I-SB can either destroy firm value due to rent-seeking behaviors or improve shareholder's

* Corresponding author.

E-Mail address:.joni@eco.maranatha.edu

ORCID: 0000-0003-2768-2518 
value through their professional monitoring. As a complementary to Agency Theory, Resource Dependence Theory argues that resourceful people as top management can benefit company by gaining more external resources and reducing environmental uncertainty/ other constraints. Firms use political connections as a vehicle to gain resources from government and to minimize boundaries when dealing with government's bureaucracy. Prior literature shows that firms with political IDs are associated better firm value, such as higher performance (Wu et al. 2012), more bank loan (Houston et al. 2014), lower cost of capital (Boubakri et al. 2012), etc. However, another stream of literature finds that the presence of political IDs reduces firm value in several ways, including tunneling activities, inefficient investment, etc. This mixed result on the empirical studies is one of the challenges faced in the literature of political IDs (Hu et al. 2019). In addition, Hu et al. (2019) argue that another challenge in this literature is endogeneity issue. It is possible that firms with lower corporate's risks are more likely to appoint political I-SB. Or perhaps, the presence political I-SBs is not providing political protection or bringing government's resources or improving the monitor function because they have similar social network with the SOEs as the controlling shareholders (Hu et al. 2019).

Our study addresses these challenges and is different with previous works (e.g., Shi et al. 2018; Hu et al. 2019) by using different setting. We examine this issue under Indonesian two-tier board context. Scholars have increasingly recognised that the role of independent board is significantly influenced by institutional setting (e.g., Liu et al. 2015; Ye and Li 2017). Mostly, literature shows the value of independent board in the single board system setting, such as U.S. (e.g. Daily and Dalton 1992; Anderson et al. 2004; Cornett et al. 2009). For instance, Nguyen and Nielsen (2010) investigate the important role of independent director in US one-tier board system. They find that investors value the presence of independent directors. Using similar context, Masulis and Zhang (2018) document that firm value is lower when firms have more distracted independent directors (proxied by fewer meetings, less trading, and more resignation).

Motivated by limited studies on the value of independent board in the two-tier board context, we investigate the role of political IDs in emerging economy, Indonesia. The adoption of dual board mechanism in Indonesia is influenced by the Dutch civil law. Consequently, all listed firms are required to have separate Board of Director (BOD) who is responsible for daily operation and Board of Commissioners (BOC) who is responsible for supervising and monitoring the BOD. ${ }^{1}$ Based on this context, we focus on the value of the political Independent BOC or SB (political I-SB). We expect that the presence of political I-SB in Indonesian dual board system can reduce the corporate risk through their strategic role and capability to bring resources from government and their effective monitoring function.

Second, our study will investigate the effect of political I-SB in Joko Widodo (JOKOWI) regime. We use the first period of JOKOWI (2014-2017) as our sample. The main reason to use JOKOWI regime because JOKOWI comes from different background with previous presidents. While previous presidents have military background or the head of party (such as Soeharto, Susilo Bambang Yudhoyono-SBY, Megawati), JOKOWI is only the member of PDI-P (Partai Demokrasi Indonesia-Perjuangan) and from civil background. Further, JOKOWI is claimed to be more transparent. Lastly, we evaluate endogeneity issue by applying Generalized Method of Moments (GMM).

\footnotetext{
${ }^{1}$ BOC has similar idea with Supervisory Board (SB) in general.
} 
We outlined the remainder of the full paper as follows: in section 2, we review the prior literature and develop the main hypotheses, followed by research method in Section 3. Section 4 reports our empirical findings, and section 5 provides additional tests. Finally, section 6 shows concluding remark.

\section{Hypotheses development}

\section{Recent studies on the independent boards}

Our research is closely associated to two streams of empirical literature. Firstly, the literature on the value of independent boards. Extant empirical research investigates the effectiveness of independent boards in one-tier board context, yet limited studies on the two-tier board context. Nguyen and Nielsen (2010) examine whether the independent directors contribute or add value to shareholders in the US from 1994 to 2007 using the sudden death of individual independent directors as a natural experiment. They show a convincing evidence that firm's stock price declines after the sudden death of independent directors. This means that the role of independent director is effective and valuable in the perspective of shareholders. In addition, Masulis and Zhang (2018) estimate the value of independent directors by examining whether exogenous events (such as fewer meetings, less trading, and more resignation of the board) distract the effectiveness of the independent directors. Based on the S\&P 1500 firms from 2000 to 2013, they conclude that firms with distracted independent boards decrease firm valuation and operating performance. This also lower firm's accounting quality and M\&A (Merger and Acquisition) profitability. However, Duchin et al. (2010) use the Sarbanes-Oxley Act and new regulations which require firms to add more independent directors on their board as an exogenous shock to examine the effectiveness of independent boards in the context of US one-tier board system from 2000-2005. They document that the value of independent board is associated to the cost of obtaining firm's information. When the information cost is low, the increasing number of independent boards results better performance. On the other hand, if the information is high, the relation between independent board size and performance is statistically negative and significant.

Unlike one-tier board system, the Indonesian dual board system has board of directors (BODs) who has responsible for company's operation and supervisory boards (SBs, often called as board of commissioners) whose duty is to monitor and provide advice to BODs. The IFC (2014, International Finance Corporation) argues that SBs have several important dan strategic roles in the Indonesian corporate governance mechanism, including deciding strategic development and long-term contracts. It is expected that the presence of independent SBs reduces corporate risks through monitoring and supervision functions.

\section{Recent studies on political Independent Boards}

Next, our empirical work is also related to the growing literature of the effectiveness of political IDs. Only limited study examines the value of political IDs, and the results are mixed. For instance, Wang (2015) tests the important of political IDs using 7,487 Chinese listed firm-year observations from 2003-2012. They analyse privately controlled firms and government-controlled firms differently. This study finds that the economic consequences of having political IDs are shaped by ownership structure. Specifically, the result shows that privately controlled firms with 
political IDs obtain more benefits than non-politically affiliated firms because they have more access to external funding and more government subsidies. In addition, the presence of political IDs in privately controlled firms increase the magnitude of related party transactions with their controlling party. However, the existence of political IDs in government-controlled firms do not add value, especially in local government-affiliated firms. It because of the expropriation of minority investors through related party transactions and over-investment issues.

Further, Shi et al. (2018) examine whether and how political IDs add or reduce firm value based on an exogenous regulatory change in China. They show several important findings. First, compared to non-political IDs, political IDs are less effective in overseeing managers (type 1 agency conflict). Second, political IDs do not create or reduce value in overseeing controlling shareholders (type 2 agency conflict). Third, the negative influence of political IDs can be reduced by high levels of marketization and analyst coverage as external corporate governance mechanisms. Cheng (2018) explores the value of political IDs by investigating market reactions to sudden deaths of political IDs in China during the period of 2003-2012. Using event study, they find that politically connected private listed firms suffer loss due to the sudden death of a political IDs. The share price reduces $3.61 \%$ on average around ten trading days. Also, the sudden death of political IDs reduces the economic benefits of the politically connected private firms, including bank loan, tax preference, and government subsidies.

Recently, Hu et al. (2019) examine the value of political IDs using an exogenous shock (a 2013 regulatory 18 shock) which stops firms to have political IDs. Specifically, they investigate whether Chinese listed firms with political IDs increase their firm value (having more long-term borrowing) and decrease firm value (increasing minority shareholder's expropriation) before the regulatory 18 . This empirical study contributes to the literature by using exogenous shock to address the endogeneity issue. They find that a 2013 regulatory 18 shock which reduces the number of political IDs causes the reduction of long-term debt financing and government subsidies for non-SOEs. In addition, they show that non-SOEs with the sudden loss of political IDs enhance the protection of minority shareholders by reducing self-dealing activities and improving investment efficiency.

While prior studies address the inconclusive findings on the relation between political IDs and firm value by using exogenous events as a natural experiment to reduce endogeneity problem, we add contribution to the literature by investigating whether political IDs reduce corporate's risks in JOKOWI regime. JOKOWI's regime is different with other presidents in several ways. First, he comes from different party with previous president-SBY. It means that they have different political directions. JOKOWI is supported by PDIP (Partai Demokrasi Indonesia Perjuangan) and SBY is from Demokrat party. Second, other presidents are head of the party, such as SBY is the head of Demokrat party (elite), but JOKOWI is only the member of PDIP party. Third, JOKOWI represents the interest of the people of Indonesia because he comes from civil background compared to other presidents, including SBY and Soeharto, who come from military background. Forth, JOKOWI promotes clean government and transparency more than SBY's regime or prior regime.

In line with the theoretical background and the estimation of the prior empirical evidence, the following hypothesis is proposed: 
H1: A firm with political independent supervisory boards is associated with lower corporate's risks compared to their counterpart in the context of Indonesian dual board system, ceteris paribus.

\section{Research method}

\section{Data and sample}

To estimate the empirical model of the study, we collected all Indonesian publicly listed companies from 2015 to 2017, except financial industries because they are regulated under different system. Our data consists of financial and non-financial information. First, our corporate governance data, including political I-SBs, is hand-collected from corporate's annual reports, institution website, and other search engines, such as Google, Yahoo, etc. Second, we also obtain the financial information from Datastream.

Next, we eliminate observations with incomplete required information in our sample. As a result, our final sample is reduced to 1,176 firm-year observations for operating risk estimation and 1,254 firm-year observations for market risk estimation (Table 1, Panel A). In Panel B of Table 1, the number of firms with political independent supervisory board members varies by year in operating risk analyses, with 167 firms (43.5\%) in 2015, 169 firm-year observations (44.1\%) in 2016, and 179 (42.5\%) in 2017. For market risk, the percentage of companies with politically affiliated independent supervisory boards are 43.5\%, 43.3\%, 40.9\% for the years 2015, 2016 and 2017, respectively.

Table 1. The Sample Description

\begin{tabular}{|c|c|c|c|c|c|}
\hline \multicolumn{6}{|c|}{ Panel A: The selection of the sample (SDROA: operating risk/VOL: market risk) } \\
\hline No. & Fiscal year & 2015 & 2016 & 2017 & $\begin{array}{l}\text { Total } \\
\text { observations }\end{array}$ \\
\hline 01. & $\begin{array}{l}\text { Number of listed firms in } \\
\text { IDX }\end{array}$ & 582 & 582 & 582 & 1,746 \\
\hline 02. & $\begin{array}{l}\text { Number of listed firms with } \\
\text { missing data }\end{array}$ & $210(\mathbf{1 9 1})$ & 199 (176) & $161(\mathbf{1 2 5})$ & $570(\mathbf{4 9 2})$ \\
\hline Tota & ted firms in the sample & $372(391)$ & $383(\mathbf{4 0 6})$ & $421(\mathbf{4 5 7})$ & $1,176(\mathbf{1}, \mathbf{2 5 4})$ \\
\hline \multicolumn{6}{|c|}{ Panel B: Distribution of firms with politically affiliated independent supervisory board (SDROA/VOL) } \\
\hline No. & Fiscal year & 2015 & 2016 & 2017 & $\begin{array}{l}\text { Total } \\
\text { observations }\end{array}$ \\
\hline 01 & $\begin{array}{l}\text { Firms with politically } \\
\text { affiliated independent } \\
\text { supervisory board }\end{array}$ & $167(\mathbf{1 7 0})$ & 169 (176) & 179 (187) & $515(\mathbf{5 3 3})$ \\
\hline 02 & $\begin{array}{l}\text { Percentage of firms with } \\
\text { politically affiliated } \\
\text { independent supervisory } \\
\text { board }\end{array}$ & $44.9 \%(\mathbf{4 3 . 5 \%})$ & $44.1 \%(\mathbf{4 3 . 3 \%})$ & $42.5 \%(\mathbf{4 0 . 9 \% )}$ & $43.8 \%(\mathbf{4 2 . 5 \%})$ \\
\hline
\end{tabular}




\section{Models and variables}

We examine the following regression models to investigate the effect of politically affiliated independent SBs on corporate risks in hypothesis1. The first model is to investigate the association between political I-SBs and operating risk, and the second model is to estimate the effect of political I-SBs on market risk. The models are presented as follow:

$$
\begin{aligned}
& \mathrm{SDROA}_{\mathrm{it}}=\alpha{ }_{1} \mathrm{PC}_{-} \mathrm{SBIND}_{\mathrm{it}}+\alpha_{2} \mathrm{SBIND}_{-} \mathrm{APPOINTED}{ }_{\mathrm{it}}+\alpha_{3} \mathrm{SBIND}_{-} \text {TENURE }{ }_{\mathrm{it}}+\alpha_{4} \mathrm{SBIND}_{5} \mathrm{FIN}_{\mathrm{it}} \\
& +\alpha_{5} \mathrm{SOE}_{\mathrm{it}}+\alpha_{6} \mathrm{FSIZE}_{\mathrm{it}}+\alpha_{7} \mathrm{MTB}_{\mathrm{it}}+\alpha_{8} \mathrm{IND}_{\mathrm{it}}+\alpha_{9} \mathrm{YEAR}_{\mathrm{it}}+\varepsilon \text { it }
\end{aligned}
$$

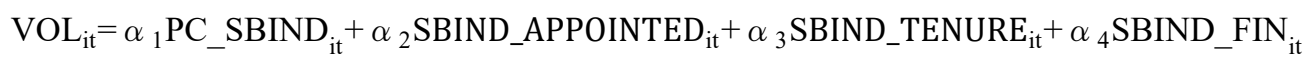

$$
\begin{aligned}
& +\alpha_{5} \mathrm{SOE}_{\mathrm{it}}+\alpha_{6} \mathrm{FSIZE}_{\mathrm{it}}+\alpha_{7} \mathrm{MTB}_{\mathrm{it}}+\alpha_{8} \mathrm{IND}_{\mathrm{it}}+\alpha_{9} \mathrm{YEAR}_{\mathrm{it}}+\varepsilon_{\text {it }}
\end{aligned}
$$

\begin{tabular}{|c|c|}
\hline Variable & Definition \\
\hline $\mathrm{SDROA}_{i t}$ & $\begin{array}{l}\text { A five years standard deviation of ROA for firm i in year t (e.g., from t-4 } \\
\text { to t) (Harjoto and Laksmana 2018) }\end{array}$ \\
\hline $\mathrm{VOL}_{\mathrm{it}}$ & $\begin{array}{l}\text { The standard deviation of daily stock returns for for firm } \mathrm{i} \text { in year } \mathrm{t} \\
\text { (Harjoto and Laksmana 2018) }\end{array}$ \\
\hline PC_SBIND ${ }_{\text {it }}$ & $\begin{array}{l}\text { A dummy variable, set as } 1 \text { if political I-SB is exist for firm } i \text { in year } t \text { and } \\
0 \text { otherwise (Faccio 2006) }\end{array}$ \\
\hline
\end{tabular}

We organise the detailed definition of variables and sources as follow:

\begin{tabular}{|c|c|}
\hline SBIND_APPOINTED $_{\text {it }}$ & $\begin{array}{l}\text { The independent Supervisory Board is appointed by BOD for firm i in } \\
\text { year } t \text { (Nguyen and Nielsen 2010) }\end{array}$ \\
\hline SBIND_TENURE $_{\text {it }}$ & $\begin{array}{l}\text { The years of tenure on the independent SB for firm } \mathrm{i} \text { in year } \mathrm{t} \text { (Nguyen and } \\
\text { Nielsen 2010) }\end{array}$ \\
\hline SBIND_FIN & $\begin{array}{l}\text { The percentage of independent supervisory board members who have } \\
\text { financial and accounting background for firm } \mathrm{i} \text { in year } \mathrm{t} \text { (Xie et al. 2003) }\end{array}$ \\
\hline $\mathrm{SOE}_{\mathrm{it}}$ & $\begin{array}{l}\text { A dummy variable, set as one if the controlling owner is a central or local } \\
\text { government for firm } i \text { in year } t \text { and zero otherwise (Hu et al. 2019) }\end{array}$ \\
\hline FSIZE $_{i t}$ & $\begin{array}{l}\text { The natural log of the company's total assets for firm } \mathrm{i} \text { in year } \mathrm{t} \text { (Harjoto } \\
\text { and Laksmana 2018) }\end{array}$ \\
\hline MTB $_{\text {it }}$ & $\begin{array}{l}\text { The ratio of market value of equity for firm } t \text { in year } t \text { (Harjoto and } \\
\text { Laksmana 2018) }\end{array}$ \\
\hline
\end{tabular}

Firm and board characteristics as control variables

Fixed effects as control variables

\begin{tabular}{ll}
\hline IND $_{\text {it }}$ & a vector of industry indicator variables is grouped using two-digit GICS \\
& (Global Industry Classification Standard). \\
YEAR $_{\text {it }}$ & a vector of year indicator variables: $2015 ; 2016 ; 2017$. \\
\hline
\end{tabular}




\section{Statistical analyses}

We utilize OLS regression models to estimate all hypotheses. First, we provide descriptive statistics to have better understanding of the raw data and useful information for our main analysis. Second, we use correlation analysis to obtain initial understanding on the association among main variables. Then, this analysis is used to identify the presence of multicollinearity problem in the main models. We also check multicollinearity problem by using variance inflation factor (VIF) for each model. Third, we estimate the main hypotheses using OLS regression model. This method is consistent with previous studies (e.g. Hu et al. 2019; Shi et al. 2018).

\section{Sensitivity analyses}

As mentioned earlier, one potential problem to examine the relation between political I-SBs and corporate risks is endogeneity. It is possible that risky firms tend to have political connections to hide their unethical behavior. So, the political affiliated I-SBs can be endogenously determined. To address the possibility of endogeneity issue, we apply the difference Generalized Method of Moments (GMM) as additional test. As a complementary estimation, GMM is also an efficient model in the presence of heteroskedasticity (Baum et al., 2003).

\section{Empirical findings}

\section{Descriptive statistics}

In Table 3, we report descriptive statistics of the main variables in the full sample of 1,176 observations in operating risk analysis and 1,254 observation in market risk analysis. Operating risk/SDROA (or market risk/VOL) is the dependent variable which has an average value of 0.044 (0.029) with a minimum value of $0.002(0.000)$ and maximum value of 0.511 (0.174). The mean of politically affiliated independent supervisory board (PC_SBIND) is 0.438 (0.425) with a maximum value of $1.000(1.000)$ and a minimum value of $0.000(0.000)$ for operating risk and market risk models, respectively. The descriptive statistics of our key variables are consistent with previous studies such as Hu et al. (2019), Joni et al. (2019), Harjoto and Laksmana (2018). In general, the value of corporate risks and politically affiliated independent supervisory board variables in the sample are considered reasonable. Next, we estimate pairwise Pearson correlations to report the correlations of several main variables in Table 4, except for the industry and year variables. The highest correlation exists between SDROA and FSIZE ( $\mathrm{r}=0.221)$ at the $1 \%$ level in operating risk analysis. Further, we test multicollinearity issue using variance inflation factor (VIF) in Table 5. It shows that the average VIF for politically independent SB and corporate risk is about 1.14, suggesting that none of the results suffer from multicollinearity. 
Table 3. Descriptive statistics of our key variables

\begin{tabular}{lcccccccccc}
\hline \multicolumn{1}{c}{ Variable } & $\mathrm{N}$ & Mean & St. Dev & Min & Max & $\mathrm{N}$ & Mean & St. Dev & Min & Max \\
\hline SDROA/VOL & 1176 & 0.044 & 0.064 & 0.002 & 0.511 & 1254 & 0.029 & 0.017 & 0.000 & 0.174 \\
PC_SBIND & 1176 & 0.438 & 0.496 & 0.000 & 1.000 & 1254 & 0.425 & 0.495 & 0.000 & 1.000 \\
SBIND_APPOINTED & 1176 & 0.936 & 1.042 & 0.000 & 7.000 & 1254 & 0.922 & 1.033 & 0.000 & 7.000 \\
SBIND_TENURE & 1176 & 5.613 & 5.488 & 0.500 & 28.000 & 1254 & 5.441 & 5.424 & 0.500 & 28.000 \\
SBIND_FIN & 1176 & 0.527 & 0.384 & 0.000 & 2.000 & 1254 & 0.532 & 0.406 & 0.000 & 5.000 \\
SOE & 1176 & 0.039 & 0.193 & 0.000 & 2.000 & 1254 & 0.037 & 0.188 & 0.000 & 1.000 \\
FSIZE & 1176 & 27.34 & 3.782 & 13.000 & 35.000 & 1254 & 27.310 & 3.740 & 13.000 & 35.000 \\
MTB & 1176 & 2.61 & 3.990 & -0.010 & 18.760 & 1254 & 2.729 & 4.102 & -0.010 & 18.760 \\
\hline
\end{tabular}

Notes: The table documents the summary statistics of the key variables. The sample includes $1,176(1,254)$ firm-year observations from 2015 to 2017. Variable definitions are shown in Table 2.

Table 4. The Pearson Correlation Matrix of Key Variables

\begin{tabular}{lcccccccc}
\hline \multicolumn{1}{c}{ Variable } & 1 & 2 & 3 & 4 & 5 & 6 & 7 \\
\hline SDROA/VOL (1) & 1.000 & $-0.079^{\mathrm{a}}$ & $-0.095^{\mathrm{a}}$ & -0.037 & 0.000 & $-0.073^{\mathrm{b}}$ & $-0.148^{\mathrm{a}}$ & -0.002 \\
PC_SBIND (2) & $-0.067^{\mathrm{b}}$ & 1.000 & $0.129^{\mathrm{a}}$ & $-0.072^{\mathrm{b}}$ & $0.059^{\mathrm{b}}$ & $0.107^{\mathrm{a}}$ & 0.030 & $0.052^{\mathrm{c}}$ \\
SBIND_APPOINTED (3) & $-0.088^{\mathrm{a}}$ & $0.118^{\mathrm{a}}$ & 1.000 & $0.181^{\mathrm{a}}$ & 0.024 & $0.183^{\mathrm{a}}$ & $0.195^{\mathrm{a}}$ & $0.092^{\mathrm{a}}$ \\
SBIND_TENURE (4) & $-0.052^{\mathrm{c}}$ & $-0.087^{\mathrm{a}}$ & $0.175^{\mathrm{a}}$ & 1.000 & $-0.141^{\mathrm{a}}$ & $-0.115^{\mathrm{a}}$ & 0.005 & $-0.092^{\mathrm{a}}$ \\
SBIND_FIN (5) & -0.020 & $0.062^{\mathrm{b}}$ & 0.037 & $-0.138^{\mathrm{a}}$ & 1.000 & 0.030 & $0.074^{\mathrm{a}}$ & 0.027 \\
SOE (6) & $-0.076^{\mathrm{a}}$ & $0.105^{\mathrm{a}}$ & $0.185^{\mathrm{a}}$ & $-0.124^{\mathrm{a}}$ & 0.036 & 1.000 & $0.143^{\mathrm{a}}$ & $0.063^{\mathrm{b}}$ \\
FSIZE (7) & $-0.221^{\mathrm{a}}$ & 0.029 & $0.195^{\mathrm{a}}$ & 0.001 & $0.093^{\mathrm{a}}$ & $0.144^{\mathrm{a}}$ & 1.000 & $0.087^{\mathrm{a}}$ \\
MTB (8) & $-0.063^{\mathrm{b}}$ & $0.055^{\mathrm{c}}$ & $0.095^{\mathrm{a}}$ & $-0.076^{\mathrm{a}}$ & $0.020^{\mathrm{c}}$ & $0.073^{\mathrm{b}}$ & $0.091^{\mathrm{a}}$ & 1.000 \\
\hline
\end{tabular}

The table presents the pairwise Pearson correlation matrix for the full sample $(1,176[1,254]$ firm-year observations). The superscripts a-c describe significance at the $1 \%, 5 \%$, and $10 \%$ levels, respectively. Variable definitions are shown in table 2.

\section{Politically affiliated independent SB and corporate's risks}

We report the Ordinary Least Square estimates for examining the association between political independent SB and corporate risks in Table 5 . Model 1 of Table 5 show a negative association between politically affiliated independent SBs and corporate operating risk, and it is statistically significant at the $5 \%$ level (coefficient $=-0.007, t=-1.96$ ). Also, we find that the relation between firms with political independent SBs and corporate market risk is significantly negative at the $1 \%$ level (coefficient $=-0.002, t=-2.48$ ). Following previous literature (e.g. Joni et al. 2019; Shi et al. 2018), Table 5 reports the significant results after controlling for other Independent SB characteristics (such as Independent SB appointed by BOD, tenure, and Independent SB with financial background), market to book ratio, SOE, and firm size.

Overall, our findings are consistent with previous studies (Hu et al. 2019; Joni et al. 2019), suggesting that the presence of politically affiliated independent SB reduce either corporate operating or market risks. The role of independent SB in the context of two-tier board mechanism, such as Indonesia, is very important and strategic as they monitor and supervise Board of Director. Not only that, they also have authority to make approval of long-term investment and corporate strategic plan (Joni et al. 2019). When independent SB have political connection, their role 
is even more strategic because their connections can help company to obtain more external resources, including easier access to external funding. Consequently, the presence of political affiliated independent SB lower corporate risks.

Table 5. Political Affiliated Independent SB and corporate's risks

\begin{tabular}{lll}
\hline Variables & \multicolumn{2}{l}{ Estimated coefficient } \\
\cline { 2 - 3 } & Model 1: SDROA & Model 2: VOL \\
\hline INTERCEPT & $0.130^{\mathrm{a}}(8.84)$ & $0.049^{\mathrm{a}}(12.57)$ \\
PC_SBIND & $-0.007^{\mathrm{b}}(-1.96)$ & $-0.002^{\mathrm{a}}(-2.48)$ \\
SBIND_APPOINTED & $-0.001(-0.81)$ & $-0.000^{\mathrm{c}}(-1.78)$ \\
SBIND_TENURE & $-0.000^{\mathrm{b}}(-1.98)$ & $-0.000(-1.07)$ \\
SBIND_FIN & $0.003(0.67)$ & $-0.000(-0.31)$ \\
SOE & $-0.012(-1.29)$ & $-0.004(-1.61)$ \\
FSIZE & $-0.003^{\mathrm{a}}(-5.23)$ & $-0.000^{\mathrm{a}}(-5.03)$ \\
MTB & $-0.000^{\mathrm{c}}(-1.69)$ & $0.000^{\mathrm{a}}(0.50)$ \\
YEAR & Included & Included \\
INDUSTRY & Included & Included \\
& & \\
Mean VIF & 1.14 & 1.14 \\
$\mathrm{R}^{2}$ & 0.097 & 0.056 \\
F & $8.96^{\mathrm{a}}$ & $5.21^{\mathrm{a}}$ \\
Prob > F & 0.000 & 0.000 \\
$\mathrm{~N}$ & 1,176 & 1,254 \\
\hline
\end{tabular}

The table shows Ordinary Least Square (OLS) coefficient estimates. Also, we include dummy variables in the regression to control for year and industry differences. However, the results are not provided due to space constraints. The superscripts a-c describe significance at the $1 \%, 5 \%$, and $10 \%$ levels, respectively. Variable definitions are explained in table 2.

\section{Further test}

In corporate governance literature, it is important to address endogeneity problem. It is possible that less risky firms tend to have more political connection with government. We check endogeneity issue using Generalized Method of Moments (GMM). As shown in Table 6, after controlling for endogeneity, we find consistent results with our main OLS model in Table 5. 
Table 6. Political Affiliated Independent SB and firm's risks - GMM

\begin{tabular}{lll}
\hline Variables & \multicolumn{2}{l}{ Estimated coefficient } \\
\cline { 2 - 3 } & Model 1: SDROA & Model 2: VOL \\
\cline { 2 - 3 } INTERCEPT & $0.247^{\mathrm{a}}(4.547)$ & $-3.658^{\mathrm{a}}(-3.14)$ \\
PC_SBIND & $-0.007^{\mathrm{b}}(-1.93)$ & $-0.007^{\mathrm{a}}(-2.38)$ \\
SBIND_APPOINTED & $-0.001(-0.76)$ & $-0.000^{\mathrm{c}}(-1.78)$ \\
SBIND_TENURE & $-0.000^{\mathrm{a}}(-2.57)$ & $-0.000(-1.27)$ \\
SBIND_FIN & $0.001(0.20)$ & $-0.000(-0.20)$ \\
SOE & $-0.013^{\mathrm{a}}(-4.27)$ & $-0.003^{\mathrm{a}}(-2.89)$ \\
FSIZE & $-0.003^{\mathrm{a}}(-5.60)$ & $-0.000^{\mathrm{a}}(-5.01)$ \\
MTB & $-0.000^{\mathrm{b}}(-1.94)$ & $0.008^{\mathrm{a}}(0.39)$ \\
YEAR & Included & Included \\
INDUSTRY & Included & Included \\
N & & \\
\hline
\end{tabular}

The table shows Ordinary Least Square (OLS) coefficient estimates. Also, we include dummy variables in the regression to control for year and industry differences. However, the results are not provided due to space constraints. The superscripts a-c describe significance at the $1 \%, 5 \%$, and $10 \%$ levels, respectively. Variable definitions are explained in table 2.

\section{Conclusion Remark}

Our study investigates the effect of political independent supervisory board on corporate risks in the context of twotier board system, Indonesia. Our finding suggests that firms with political independent supervisory boards have lower corporate risks compared to their counterparts after controlling for endogeneity problem. We show that the role of politically affiliated independent supervisory board is important and strategic in dual board system. This is consistent with agency theory suggesting that the presence of political independent board is effective to oversee Board of Director and reduces agency conflicts between management and shareholders. In addition, our finding is in line with Resource Dependency Theory, meaning that political connection is an effective vehicle to lower external factors which can reduce corporate risks.

Overall, this study contributes to the corporate governance literature by showing an empirical evidence on the effectiveness of independent supervisory board with political connection in two-tier board system, while previous studies focus on one-tier board system using US sample. First, our findings imply that monitoring role of independent supervisory board in emerging market context, Indonesia, which applies dual board system, is effective. Second, our paper sheds light on the strategic role of the resourceful political independent supervisory board in assisting company to reduce external uncertainty and to obtain external resources.

Our study should be interpreted by considering several limitations. First, we examine the effect of political independent supervisory board on financial outcomes, we do not address its impact on non-financial outcomes. Second, a quantitative research has a limitation to deeply explore how politics affect corporate decision making. We leave these issues for future research to examine the effect of political independent supervisory board on non-financial outcomes using qualitative or mixed methods. 


\section{References}

Anderson, R. C., S. A. Mansi, and D. M. Reeb. 2004. Board characteristics, accounting report integrity, and the cost of debt. Journal of accounting and economics 37 (3):315-342.

Baum, C. F., M. E. Schaffer, and S. Stillman. 2003. Instrumental variables and GMM: Estimation and testing. Stata journal 3 (1):1-31.

Boubakri, N., O. Guedhami, D. Mishra, and W. Saffar. 2012. Political connections and the cost of equity capital. Journal of corporate finance 18 (3):541-559.

Cheng, L. 2018. Estimating the value of political connections in China: Evidence from sudden deaths of politically connected independent directors. Journal of comparative economics 46 (2):495-514.

Cornett, M. M., J. J. McNutt, and H. Tehranian. 2009. Corporate governance and earnings management at large US bank holding companies. Journal of corporate finance 15 (4):412-430.

Daily, C. M., and D. R. Dalton. 1992. The relationship between governance structure and corporate performance in entrepreneurial firms. Journal of Business Venturing 7 (5):375-386.

Duchin, R., J. G. Matsusaka, and O. Ozbas. 2010. When are outside directors effective? Journal of Financial Economics 96 (2):195-214

Faccio, M. 2006. Politically connected firms. The American economic review 96 (1):369-386.

Fama, E. F., and M. C. Jensen. 1983. Separation of ownership and control. Journal of law and economics:301-325.

Harjoto, M., and I. Laksmana. 2018. The impact of corporate social responsibility on risk taking and firm value. Journal of business ethics 151 (2):353-373.

Houston, J. F., L. Jiang, C. Lin, and Y. Ma. 2014. Political connections and the cost of bank loans. Journal of Accounting Research 52 (1):193-243.

Hu, R., K. Karim, K. J. Lin, and J. Tan. 2019. Do investors want politically connected independent directors? Evidence from their forced resignations in China. Journal of corporate finance.

Joni, J., K. Ahmed, and J. Hamilton. 2019. Politically connected boards, family and business group affiliations, and cost of capital: Evidence from Indonesia. The British Accounting Review:100878.

Liu, C., S. Li, and L. Sun. 2015. Do independent directors have the consulting function? An empirical study on the function of independent directors in strange land. Management World 3:124-136.

Masulis, R. W., and E. J. Zhang. 2018. How Valuable are Independent Directors? Evidence from External Distractions.

Nguyen, B. D., and K. M. Nielsen. 2010. The value of independent directors: Evidence from sudden deaths. Journal of Financial Economics 98 (3):550-567.

Pfeffer, J., and G. Salancik. 1978. The external control of organizations: a resource dependence perspective.

Shi, H., H. Xu, and X. Zhang. 2018. Do politically connected independent directors create or destroy value? Journal of Business Research 83:82-96.

Wang, L. 2015. Protection or expropriation: Politically connected independent directors in China. Journal of Banking \& Finance 55:92-106.

$\mathrm{Wu}, \mathrm{W}$., C. Wu, C. Zhou, and J. Wu. 2012. Political connections, tax benefits and firm performance: Evidence from China. Journal of accounting and public policy 31 (3):277-300.

Xie, B., W. N. Davidson, and P. J. DaDalt. 2003. Earnings management and corporate governance: the role of the board and the audit committee. Journal of corporate finance 9 (3):295-316.

Ye, Q., and Z. Li. 2017. Do independent directors play a political role? Evidence from independent directors' death events. China Journal of Accounting Research 10 (4):295-316.

(C) 2021 by the authors. Licensee ACRN Publishing, Austria, Editor in Chief Prof. Dr. Othmar M. Lehner. This article is an open access article distributed under the terms and conditions of the Creative Commons Attribution (CC BY SA) license

(https://creativecommons.org/licenses/by-sa/4.0/) 